\title{
EFFECTS OF REPLACEMENT OF FISH OIL BY SESAME SEED (SESAMUM INDICUM L.) OIL IN THE DIETS OF TIL-AQUA NATURAL MALE TILAPIA
}

\author{
*Olude, O. O. ${ }^{1}$, Alegbeleye, W. O. ${ }^{2}$, George, F. O. A. ${ }^{2}$ \\ ${ }^{1}$ Department of Marine Sciences, University of Lagos, Akoka, Nigeria.
}

${ }^{2}$ Department of Aquaculture and Fisheries Management, Federal University of Agriculture, Abeokuta, Nigeria *Corresponding author's email: oolude@unilag.edu.ng, Tel: +234-8030417417

(Received: $10^{\text {th }}$ May, 2018; Accepted: $26^{\text {th }}$ March, 2019)

\section{ABSTRACT}

\begin{abstract}
This study evaluated the effects of dietary sesame oil extracted from autoclaved, roasted and fermented sesame seed meal on growth, nutrient utilization and muscle fatty acid composition of Til-aqua natural male tilapia. Four isonitrogenous (crude protein content: 35\%) and iso-energetic (Gross energy: $19.36 \mathrm{KJ} / \mathrm{g}$ ) diets were formulated to contain 3\% of either fish oil (FO) or oils extracted from autoclaved (AO), roasted (RO) or fermented (FEO) sesame seed meals. Each diet was assigned to duplicate groups of Til-aqua natural male tilapia (initial average weight, $2.78 \pm 0.02 \mathrm{~g}$ ) using recirculating aquaculture systems for 56 days. Specific growth rate $\left(2.93 \%\right.$ /day) and metabolic growth rate $\left(9.68 \mathrm{~g} / \mathrm{kg}^{0.8} /\right.$ day $)$ recorded in the group fed RO diet were significantly lower $(\mathrm{P}<0.05)$ than those of $\mathrm{AO}$ treatment. Muscle fatty acid compositions were consistent with their dietary values except for di-homo- $\gamma$-linolenic acid, 20:3 (n-6), which accumulated in the groups that received diets FO (58.11\%), FEO (44.75\%) and RO (23.30\%). There was a significant increase $(\mathrm{P}<0.05)$ in the muscle content of palmitic acid of the group fed diet AO (26.6\%) when compared with the control $(7.30 \%)$, diet RO $(18.74 \%)$ and diet FEO (11.43\%). The study showed that sesame oil can replace fish oil in the diets of tilapia without compromise on growth or nutrient utilization.
\end{abstract}

Keywords: Fish oil, Sesame seed oil, Fatty acid, Tilapia, Nutrient digestibility

\section{INTRODUCTION}

Fish oil is the conventional source of lipid in aquaculture diets because of its palatability and properly balanced fatty acid profile (Bendiksen et al., 2011). However, there are some limitations associated with its use. For instance, the use of fish oil is not sustainable because it is largely produced from small marine pelagic fish most of which are declining (FAO, 2012). Lipid peroxidation of fish muscle as indicated by the concentration of thiobarbituric acid-reactive substances (TBARS) is another problem associated with high levels of dietary fish oil (Figueiredo-Silva et al., 2005). Concern has also been raised on costeffectiveness of using fish oil in aquaculture diets (Turchini et al., 2009; FAO, 2012). Consequently, various researchers have explored alternatives to fish oil using vegetable oils. These researchers have shown that substantial quantities of vegetable oils such as palm oil and its fractions $(\mathrm{Ng}$ et al., 2003, 2004; Bahurmiz and Ng, 2007), soybean oil (Figueiredo-Silva et al., 2005) and sunflower oil (Bransden et al., 2003) can be used to substitute fish oil in fish diets without any negative impacts on growth performance, nutrient utilization and flesh quality.
Sesame (Sesamum indicum) is an annual self pollinating plant with an erect, pubescent, branching stem having seeds that contain about $50 \%$ oil (El Khier et al., 2008). Unlike sesame seed meal which has been tested severally in animal feed, there is dearth of information on the use of sesame oil as a replacement for the conventional fish oil in fish feed. Sesame oil shows high stability to oxidation compared to other vegetable oils due to the presence of some compounds known as lignans: namely sesamin, sesamolin and a small amount of sesamol among other important biologically active compounds such as tocopherols and their homologues (Rangkadilok et al., 2010).

The farming of tilapia is the most widespread type of aquaculture in the world and only second to carps in terms of global production figures (FAO, 2014; Wang and $\mathrm{Lu}, 2016)$. However, tilapia is a multi-season breeder and juveniles mature as early as three months, thus exhibiting a disadvantage of over-population which leads to stunted growth (Gupta and Acosta, 2004). All-male tilapia culture achieved through manual sexing, interspecific hybridization and hormonal sex reversal is one of 
several methods that have been employed to avoid loss of marketable biomass which occurs as a result of excess reproduction. These efforts, however, are not without their limitations. For instance, manual sexing is laborious, timeconsuming, requires experienced personnel and usually results in $3-10 \%$ sex errors; there is the problem of keeping pure lines of broodstock to achieve predominantly all-male progeny in interspecific hybridization while hormonal sex reversal has been frowned at because of its environmental and social implications (Gupta and Acosta, 2004).

The use of hormones to achieve monosex populations in fish has been reported to have a strong negative effect on the immune system of fish (Harris and Bird, 2000). Developing male broodstocks that have two Y chromosomes (YY) and no $\mathrm{X}$ chromosome through genetic manipulation is another effort aimed at achieving monosex population in tilapias. When the YY males are crossed with females (XX) from separate mixed sex line, it results in predominantly all male progeny (Subasinghe et al. 2003). Til-aqua red natural male tilapia (NMT) used under current investigation were produced using $\mathrm{YY}$ male technology without the use of hormone at any point and they have been shown to exhibit improved growth performance, nutrient utilization and resistance to diseases (Islam et al. 2015)

This study was undertaken to investigate the effects of dietary sesame oil extracted from autoclaved, roasted and fermented sesame seed meal on growth, nutrient utilization and muscle fatty acid composition of Til-aqua NMT.

\section{MATERIALS AND METHODS Experimental System}

The experiment was conducted at the fish hatchery of Durante Fish Industries Limited, Old Nigerwest Building, Orita Challenge, Ibadan, in eight recirculating systems. The systems were supplied with water from an overhead $7500 \mathrm{~L}$ capacity tank. The components and specifications of the system were earlier detailed in Olude et al. (2016). Briefly, the system consisted of rectangular plastic rearing tanks (volume: 445 litres), 11-Watts ultraviolet bulb to inactivate bacteria, polyvinyl chloride bio-filter blocks for processing of fish waste and a submersible pump (Aquamaxima, $7500 \mathrm{~L} / \mathrm{h}$ ) for recycling water. Water loss through splashing and evaporation was compensated for by daily addition of water from the overhead tank.

\section{Diets Preparation}

All feed ingredients were collected from Durante Feed Mill, Ibadan, Oyo state, Nigeria. Sesame seeds were collected from the Institute of Food Security, Environmental Resources and Agricultural Research (IFSERAR) of the Federal University of Agriculture, Abeokuta, Nigeria. Sesame seeds weighing $7.5 \mathrm{~kg}$ were cleaned, sieved and soaked for 24 hours according to the method described by Mukhopadhyay and Ray (1999) and subsequently divided into three portions. A portion was autoclaved and another portion fermented as previously described in Olude et al. (2016). The last portion of the soaked sesame seeds were spread in a single layer in a roasting tray and roasted in an electric oven (Binder FO 115, Germany) at $200{ }^{\circ} \mathrm{C}$ for 15 minutes (Yoshida and Takagi, 1997). Subsequently, the seeds were transferred to wooden tray and allowed to cool at ambient temperature. The autoclaved, fermented and roasted sesame seeds were ground using a locally fabricated hammer mill and their oils were mechanically extracted with an improvised mechanical screw-press for 6 hours (Olude et al., 2016). The oils were stored in a well-labeled plastic bottle at room temperature. Four isonitrogenous (35\% crude protein) and isoenergetic $(19.36 \mathrm{KJ} / \mathrm{g}$ Gross Energy) diets were formulated (Table 1) using equal portion of fishmeal, fermented sesame seed meal, wheat meal and vitaminmineral premix. Lignobond was used as a binder while chromic oxide served as digestibility marker. The control diet contained fish oil as the main source of lipid while oil extracted from autoclaved, roasted and fermented sesame seed meal replaced fish oil in the other three test diets. The control diet was labeled as FO while the test diets containing oil extracted from autoclaved, roasted and fermented sesame seed meals were labeled $\mathrm{AO}, \mathrm{RO}$ and $\mathrm{FEO}$ respectively. 
Table 1: Ingredient Composition (\%) of Experimental Diets

\begin{tabular}{lllll}
\hline Ingredients $\%$ & FO & AO & RO & FEO \\
\hline Fishmeal & 38.32 & 38.32 & 38.32 & 38.32 \\
Fermented Sesame & 16.43 & 16.43 & 16.43 & 16.43 \\
Wheat meal & 38.75 & 38.75 & 38.75 & 38.75 \\
Fish oil & 3 & - & - & - \\
Autoclaved oil & - & 3 & - & - \\
Roasted oil & - & - & 3 & - \\
Fermented oil & - & - & - & 3 \\
$*$ Premix & 2 & 2 & 2 & 2 \\
Lignobond & 1 & 1 & 1 & 1 \\
Chromic oxide & 0.5 & 0.5 & 0.5 & 0.5 \\
\hline
\end{tabular}

${ }^{*}$ Hi-nutrient vitamin premix supply/100 g diet : vitamin A palmitate, 1000 IU; cholecalciferol (D), 1000 IU; $\alpha$-tocopherol acetate $(\mathrm{E}), 1.1 \mathrm{mg}$; menadione $(\mathrm{K}), 0.02 \mathrm{mg}$; thiamine B1, $0.63 \mathrm{mg}$; riboflavin(B2), $0.5 \mathrm{mg}$; pantothenic acid, $1.0 \mathrm{mg}$; pyridoxine (B6), $0.15 \mathrm{mg}$; cyanocobalamine (B12), $0.001 \mathrm{mg}$; nicotinic acid, $3.0 \mathrm{mg}$; folic acid, $0.1 \mathrm{mg}$; choline, $31.3 \mathrm{mg}$; ascorbic acid (C), $0.1 \mathrm{mg}$; ferrous sulphate, $0.05 \mathrm{mg}$; copper sulphate, $0.25 \mathrm{mg}$; manganese sulphate, $6.00 \mathrm{mg}$; cobalt chloride, $0.5 \mathrm{mg}$; zinc sulphate, $5.0 \mathrm{mg}$; sodium selenite, $0.02 \mathrm{mg}$.

\section{Experimental Procedure}

Til-aqua red NMT fry (average weight, 2.78 \pm 0.02 g) produced and reared at the hatchery of Durante Fish Industries Ltd, Ibadan was randomly distributed into eight rearing systems at the rate of 40 fish per system in a completely randomized experimental design. The experimental diets were offered in two equal installments at 0900 and 1600 hours to duplicate groups of fish. The diets were quantified based on five times the maintenance requirement $\left.\{5 \times 3.2 \times \text { [fish weight }(\mathrm{g}) / 1000]^{0.8}\right\}$ of the experimental fish according to Kumar et al. (2012). The fish were subsequently batch-weighed every seventh day with a top-loading balance (RCL-15) till the end of the experiment which lasted for 56 days. The quantity of feed fed was adjusted according to the weekly weight gain. Faeces were collected daily during the last two weeks of the feeding experiment. The faecal materials were pooled according to treatment, dried, and stored in tagged cellophane bags in a freezer $\left(-10{ }^{\circ} \mathrm{C}\right)$ for analysis. At the end of the experiment, five fish per treatment replicate were sacrificed and stored in tagged polythene bag in a freezer $\left(-10{ }^{\circ} \mathrm{C}\right)$ for carcass proximate composition.

Water temperature $\left(27.4-28.4^{\circ} \mathrm{C}\right), \mathrm{pH}(8.09-8.36)$ and Conductivity $\left(0.46-0.63 \mathrm{mScm}^{-1}\right)$ were measured using a multipurpose calibrated meter (Combo, Hanna). Pondlab oxygen test kit was used to measure dissolved oxygen (8.5-10 $\left.\mathrm{mgl}^{-1}\right)$. Nitrite $\left(0.00-0.25 \mathrm{mgl}^{-1}\right)$ was monitored using Colombo nitrite test kit and ammonia (which was not detected) using Merck (Germany) ammonium test kit.

\section{Determination of Proximate and Fatty Acid Composition of Feed Ingredients, Diets and Fish Carcass}

All analyses for proximate composition were performed according to the method of Association of Official Analytical Chemists (AOAC, 1990). Protein ( $\mathrm{N} \times$ 6.25) was determined using the micro-Kjeldahl procedure, crude fat by soxtec auto fat extraction system (HT6, Tecator, Sweden) using petroleum ether and crude fibre by acid-alkali digestion method in fibertec $(1020 \mathrm{Hot}$ Extraction, Flawil, Switzerland). Gross energy content was determined by calculation, based on estimated $23.64 \mathrm{~kJ} / \mathrm{g}$ for protein, $38.50 \mathrm{~kJ} / \mathrm{g}$ for lipid and $17.15 \mathrm{~kJ} / \mathrm{g}$ for carbohydrate according to Henken et al. (1986). Lipids for fatty acid analysis was extracted from diets and fish muscle with chloroform and methanol (Bligh and Dyer, 1959), methylated and transesterified fat with boron trifluoride in methanol. Fatty acid methyl esters were resolved and analyzed by a gas-liquid chromatograph equipped with a flame ionization detector and a Chromato-Integrator. The esters were separated on a fused silica capillary column ( $30 \mathrm{~m} \times 0.32 \mathrm{~mm}$ ID). Column temperature was set 
at $50{ }^{\circ} \mathrm{C}$ for the first $2 \mathrm{~min}$, then increased to $220^{\circ} \mathrm{C}$ at $4{ }^{\circ} \mathrm{C} / \mathrm{min}$ and held at this temperature for 15 min. An injector (split ratio1:100) was used. Injector port and detector temperatures were 260 ${ }^{\circ} \mathrm{C}$. Helium was used as the carrier gas. Fatty acids were identified by comparing retention time with those of known standards (Supelco 37 Component FAME Mix; Supelco) and areas beneath the identified chromatographic peaks were calculated by integration.

\section{Analyses of Growth, Nutrient and Energy Digestibility}

Growth and nutrient utilization parameters were calculated according to standard formula (Castell and Tiews, 1980) as follow: Mean weight gain $(\mathrm{MWG})=$ Final weight - Initial weight, Average daily growth $(\mathrm{ADG})=$ Mean weight gain (g)/length of feeding trial (days), Metabolic growth rate $(M G R)=\left(W_{f_{\text {inal }}}-\right.$ $\left.\mathrm{W}_{\text {initial }}\right) /\left[\left\{\left(\mathrm{W}_{\text {initial }} / 1000\right)^{0.8}+\left(\mathrm{W}_{\text {final }} / 1000\right)^{0.8}\right\} / 2\right] /$ length of feeding trial (days), Specific growth rate $(\mathrm{SGR})=100\left(\ln \mathrm{W}_{\text {final }}-\ln \mathrm{W}_{\text {initial }}\right) /$ length of feeding trial (days), Feed conversion ratio $(\mathrm{FCR})=$ Feed fed (g)/ total wet weight gain (g), Protein efficiency ratio (PER) = wet weight gain $(\mathrm{g}) /$ protein fed $(\mathrm{g})$, Protein productive value $(\mathrm{PPV})=$ [(Final fish body protein - Initial fish body protein)/ Crude protein intake] x 100, Lipid productive value $(\mathrm{LPV})=[($ Final fish body lipid Initial fish lipid)/ Crude lipid intake] x 100 and Energy retention value $($ ERV $)=100 \times$ [ Final fish body energy - Initial fish body energy)/ Gross energy intake in feed]. The condition factor of fish at the end of the experiment was calculated according to Nash et al. (2006). Liver and visceral were excised from five fish from each replicate and weighed to determine hepatosomatic (HSI) and viscerosomatic indices (VSI) respectively using the following equations: HSI $=100 \mathrm{x}$ (liver weight/body weight); VSI $=100 \mathrm{x}$ (viscera weight/body weight).
$\mathrm{ADC}(\%)=100-\left(100 \times \frac{\% \text { Chromic oxide in diet } \mathrm{x} \% \text { nutrient/energy in faeces }}{\% \text { Chromic oxide in faeces } \mathrm{x} \% \text { nutrient/energy in diet }}\right)$

Apparent digestibility coefficients (ADC) for protein, lipid and energy were determined using the acid digestion method of Furukawa and Tsukahara (1966) and calculated according to the relationship:

\section{Data Analysis}

Data obtained from the feeding trials were analysed using a one-way analysis of variance (ANOVA) as described by Gomez and Gomez (1984). Mean differences between treatments were tested for significance $(\mathrm{P}<0.05)$ using Duncan's Multiple Range Test (Duncan, 1955).

\section{RESULTS}

\section{Proximate and Fatty Acid Composition of Experimental Diets}

The proximate composition of diets used in this study is presented in table 2 . The values of crude protein ranged between $35.15 \%$ and $36.87 \%$. Ether extract, crude fibre and gross energy contents had the following values: 13.04 to $15.33 \%, 1.31$ to $1.45 \%$ and 18.46 to $19.74 \mathrm{KJ} / \mathrm{g}$ respectively. Fatty acids composition recorded is shown in table 3 . The total saturated fatty acids was lowest $(26.17 \%)$ in the $\mathrm{RO}$ diet while the FO diet $(35.18 \%)$ had the highest; total monounsaturated fatty acids (mainly oleic acid, $18: 1(\mathrm{n}-9)$ ) ranged from $31.97 \%$ in the FO diet to $34.67 \%$ in the RO diet. The contents of linoleic acid, 18:2(n-6), and palmitic (16:0) of the control and dietary treatments were high with value range of $(22.72-32.69 \%)$ and (12.99-16.19\%), respectively. The FO diet contained higher contents of linolenic acid (18:3(n-3)) $(2.40 \%)$ and docosahexaenoic $(22: 6(n-3)) \quad(3.71 \%)$ than the treatment groups; though the values were not significant $(\mathrm{P}>0.05)$. The arachidonic acid $(20: 4(n-6))$ contents of the diets were generally low with value range of $0.99 \%$ in $\mathrm{FEO}$ diet to $1.76 \%$ in $\mathrm{AO}$ diet. 
Table 2: Proximate Composition (\%) and Gross Energy (KJ/g) of Experimental Diets

\begin{tabular}{lllll}
\hline & FO & AO & RO & FEO \\
\hline Moisture & 13.70 & 8.20 & 9.60 & 8.90 \\
Crude protein & 35.87 & 36.87 & 36.82 & 35.15 \\
Ether Extract & 13.04 & 14.69 & 14.93 & 15.33 \\
Crude fibre & 1.45 & 1.43 & 1.31 & 1.44 \\
Ash & 8.76 & 9.23 & 8.93 & 9.19 \\
$\mathrm{NFE}$ & 27.18 & 29.58 & 28.41 & 29.99 \\
Gross energy KJ/g & 18.46 & 19.74 & 19.60 & 19.65 \\
\hline
\end{tabular}

NFE - Nitrogen free extract

Table 3: Fatty Acid Composition (\% of Total Fatty Acids) of Experimental Diets

\begin{tabular}{|c|c|c|c|c|}
\hline Fatty Acid & $\mathrm{FO}$ & $\mathrm{AO}$ & $\mathrm{RO}$ & $\mathrm{FEO}$ \\
\hline $12: 0$ & nd & 0.85 & 0.51 & 1.00 \\
\hline $14: 0$ & 5.23 & 2.13 & 2.56 & 2.24 \\
\hline $14: 1$ & 0.31 & nd & nd & nd \\
\hline $16: 0$ & 16.19 & 13.41 & 12.99 & 13.78 \\
\hline $16: 1$ & 4.46 & 2.55 & 2.39 & 2.50 \\
\hline $17: 0$ & 0.62 & nd & nd & nd \\
\hline $17: 1$ & 0.61 & nd & nd & nd \\
\hline 18:0 & 4.93 & 5.28 & 5.32 & 5.42 \\
\hline $18: 1(n-9)$ & 23.70 & 31.12 & 31.47 & 31.29 \\
\hline $18: 2(n-6)$ & 22.72 & 32.06 & 32.69 & 31.58 \\
\hline $18: 3(n-3)$ & 2.40 & 1.86 & 2.00 & 1.83 \\
\hline $20: 3(n-6)$ & 1.32 & 0.07 & 0.21 & 1.40 \\
\hline $22: 1(n-9)$ & 0.40 & 0.03 & nd & 0.15 \\
\hline $20: 3(n-3)$ & 1.29 & 0.19 & 0.11 & nd \\
\hline $22: 0$ & 0.46 & 0.13 & 0.15 & $\mathrm{Nd}$ \\
\hline $20: 4(n-6)$ & 1.30 & 1.76 & 1.40 & 0.99 \\
\hline $23: 0$ & 6.80 & 4.14 & 3.83 & 3.76 \\
\hline $20: 5(n-3)$ & nd & nd & nd & 0.06 \\
\hline $22: 2$ & 0.10 & 0.06 & nd & nd \\
\hline $24: 0$ & 0.28 & 0.26 & 0.26 & 0.23 \\
\hline $24: 1$ & 1.84 & 0.24 & 0.29 & 0.22 \\
\hline $22: 6(n-3)$ & 3.71 & 2.86 & 2.74 & 2.56 \\
\hline Total saturates & 35.18 & 26.71 & 26.17 & 26.95 \\
\hline Total monoenes & 31.97 & 34.44 & 34.67 & 34.64 \\
\hline Total n-6 & 25.45 & 33.94 & 34.30 & 33.97 \\
\hline Total n-3 & 7.40 & 4.91 & 4.86 & 4.44 \\
\hline Total PUFA & 32.85 & 38.85 & 39.16 & 38.41 \\
\hline$n-3 / n-6$ & 0.29 & 0.14 & 0.14 & 0.13 \\
\hline
\end{tabular}

nd, not detected; PUFA, polyunsaturated fatty acid

Growth Response, Survival, Nutrient and Energy Utilization

The growth performance and nutrient utilization of fish fed the experimental diets is shown in table 4. The least specific growth rate $(2.93 \% /$ day $)$ and metabolic growth rate $\left(9.68 \mathrm{~g} / \mathrm{kg}{ }^{0.8} /\right.$ day $)$ were recorded in the group fed $\mathrm{RO}$ diet and their values were significantly lower $(\mathrm{P}<0.05)$ than $\mathrm{AO}$ treatment. Survival was high, ranging from 97.5 -
$100 \%$ and the differences were not significant $(\mathrm{P}>0.05)$ among the control and treatment groups. The feed conversion ratio, lipid productive value and energy productive value of the group fed diet AO were significantly better $(\mathrm{P}<0.05)$ than the group fed diet $\mathrm{RO}$ but statistically $(\mathrm{P}>0.05)$ similar to $\mathrm{FO}$ and FEO diets. The feed conversion ratio, lipid productive value and energy productive value of $\mathrm{AO}$ diet were 
significantly better $(\mathrm{p}<0.05)$ than $\mathrm{RO}$ diet, though statistically similar to $\mathrm{RO}$ and FEO diets.

Apparent digestibility coefficients for protein, lipid and energy are presented in table 4. The values of digestibility for protein, lipid and energy ranged as follows: 70.04-80.15\%, 75.96-85.59\% and $42.78-56.37 \%$, respectively. The digestibility of protein and energy of the group fed the RO diet was significantly lower $(p>0.05)$ than the control and $\mathrm{AO}$ groups.

Table 4: Growth Performance, Nutrient Utilization, Survival, Nutrient Digestibility and Somatic Indices of Tilaqua Red Natural Male Tilapia Fry Fed the Experimental Diets

\begin{tabular}{|c|c|c|c|c|}
\hline Parameter & $\mathrm{FO}$ & $\mathrm{AO}$ & $\mathrm{RO}$ & $\mathrm{FEO}$ \\
\hline IBW (g) & $2.78 \pm 0.00$ & $2.78 \pm 0.00$ & $2.78 \pm 0.00$ & $2.78 \pm 0.00$ \\
\hline FBW (g) & $15.95 \pm 0.37$ & $18.71 \pm 1.75$ & $14.28 \pm 0.12$ & $17.65 \pm 1.91$ \\
\hline MWG (g) & $13.17 \pm 0.37$ & $15.93 \pm 1.24$ & $11.50 \pm 0.12$ & $14.87 \pm 1.91$ \\
\hline SGR ( \%/day) & $3.12 \pm 0.04 \mathrm{ab}$ & $3.40 \pm 0.12^{\mathrm{a}}$ & $2.93 \pm 0.02^{\mathrm{b}}$ & $3.29 \pm 0.19 \mathrm{ab}$ \\
\hline $\operatorname{MGR}(\mathrm{g} / \mathrm{kg} 0.8 /$ day $)$ & $10.34 \pm 0.14^{\mathrm{ab}}$ & $11.26 \pm 0.39 \mathrm{a}$ & $9.68 \pm 0.05^{b}$ & $10.90 \pm 0.64^{\mathrm{ab}}$ \\
\hline FCR & $1.09 \pm 0.01 \mathrm{ab}$ & $0.97 \pm 0.04^{b}$ & $1.18 \pm 0.01^{\mathrm{a}}$ & $1.01 \pm 0.08^{\mathrm{ab}}$ \\
\hline PER & $2.58 \pm 0.02$ & $2.79 \pm 0.12$ & $2.32 \pm 0.01$ & $2.83 \pm 0.23$ \\
\hline LER & $7.08 \pm 0.05^{\mathrm{a}}$ & $7.01 \pm 0.30^{a}$ & $5.70 \pm 0.01^{b}$ & $6.48 \pm 0.52^{\mathrm{ab}}$ \\
\hline PPV (\%) & $33.91 \pm 2.28$ & $43.49 \pm 3.63$ & $34.55 \pm 1.84$ & $40.56 \pm 3.23$ \\
\hline LPV $(\%)$ & $45.46 \pm 0.99 \mathrm{ab}$ & $66.08 \pm 11.84^{\mathrm{a}}$ & $38.78 \pm 1.20^{\mathrm{b}}$ & $32.72 \pm 3.00^{\mathrm{b}}$ \\
\hline $\operatorname{EPV}(\%)$ & $31.24 \pm 0.76^{\mathrm{ab}}$ & $41.29 \pm 5.03^{\mathrm{a}}$ & $27.90 \pm 0.40^{\mathrm{b}}$ & $30.04 \pm 2.40^{\mathrm{b}}$ \\
\hline $\mathrm{ADC}_{\text {protein }}$ & $78.93 \pm 1.88^{a}$ & $80.15 \pm 1.09 a$ & $70.04 \pm 2.54 \mathrm{~b}$ & $75.98 \pm 0.05^{\mathrm{ab}}$ \\
\hline $\mathrm{ADC}_{\text {lipid }}$ & $79.18 \pm 0.21^{\mathrm{ab}}$ & $85.59 \pm 1.24^{a}$ & $75.96 \pm 4.11^{b}$ & $81.09 \pm 1.33^{\mathrm{ab}}$ \\
\hline $\mathrm{ADC}_{\text {energy }}$ & $52.09 \pm 2.21^{\mathrm{a}}$ & $56.37 \pm 2.68^{a}$ & $42.78 \pm 1.39^{b}$ & $49.63 \pm 0.91^{\mathrm{ab}}$ \\
\hline HIS & $1.06 \pm 0.03$ & $1.04 \pm 0.01$ & $1.03 \pm 0.00$ & $1.05 \pm 0.01$ \\
\hline VSI & $5.08 \pm 0.95$ & $4.84 \pm 0.10$ & $5.45 \pm 0.04$ & $5.31 \pm 0.35$ \\
\hline $\mathrm{CF}$ & $1.74 \pm 0.04$ & $1.70 \pm 0.06$ & $1.77 \pm 0.04$ & $1.72 \pm 0.02$ \\
\hline Survival & $99.00 \pm 1.00$ & $99.00 \pm 1.00$ & $100.00 \pm 0.00$ & $97.50 \pm 2.50$ \\
\hline
\end{tabular}

Data are mean values \pm Standard error; means in the same row with the same letter are not significantly different $(P>0.05)$. IBW, Initial body weight; FBW, final body weight; MWG, Mean weight gain; SGR, Specific growth rate; MGR, Metabolic growth rate; FCR, feed conversion ratio; PER, protein efficiency ratio; LER, lipid efficiency ratio; PPV, protein productive value; LPV, lipid productive value; ERV, energy retention value; HSI, Hepatosomatic index; VSI, Viscerosomatic index; CF, Condition factor

The proximate composition of fish carcass is shown in table 5 . The proximate compositions of fish carcass were similar in the control and the experimental groups with values ranging between 13.12 and $15.15 \%, 19.24$ and $19.86 \%$, respectively. AO diet favoured significantly higher $(\mathrm{P}<0.05)$ crude lipid deposition $(8.76 \%)$ than the FO and FEO diets. Fish fed AO diet was significantly lower $(\mathrm{P}>0.05)$ in body moisture content $(71.93 \%)$ while those fed RO diet was significantly lower $(\mathrm{P}>0.05)$ in body ash $(2.80 \%)$ than the other dietary groups. The muscle fatty acid composition is presented in table 6 . In general, the fatty acid found in high concentrations in the diets were also the most abundant in the muscle with the exception of di-homo- $\gamma$-linolenic (20:3 n-6) acids which accumulated in the groups that received FO (58.11\%), FEO (44.75\%) and RO $(23.30 \%)$ diets. There was a significant increase in the muscle content of palmitic acid of the group fed AO $(26.6 \%)$ diet when compared with the control $(7.30 \%)$, RO (18.74\%) and FEO (11.43\%) diets. Similar trend was observed in muscle contents of oleic and linoleic fatty acids of the fish fed the experimental diets. There was no significant difference $(\mathrm{P}>0.05)$ in muscle contents of 
docosahexaenoic acid among the dietary treatments, however, measurably higher muscle docosahexaenoic acid was observed in the groups that received $\mathrm{AO}(2.51 \%), \mathrm{RO}(2.83 \%)$ and $\mathrm{FEO}$ $(3.20 \%)$ diets compared to the FO $(1.93 \%)$ control treatment.

Table 5: Proximate Carcass Composition of Til-aqua Red Natural Male Tilapia Fry Fed the Experimental Diets

\begin{tabular}{llllll}
\hline Composition & Initial & FO & AO & RO & FEO \\
\hline Moisture \% & 74.20 & $76.16 \pm 0.46^{\mathrm{a}}$ & $71.93 \pm 1.58^{\mathrm{b}}$ & $76.19 \pm 0.46^{\mathrm{a}}$ & $76.64 \pm 0.11^{\mathrm{a}}$ \\
Crude Protein \% & 12.85 & $13.12 \pm 0.80$ & $15.15 \pm 0.57$ & $14.54 \pm 0.67$ & $14.12 \pm 0.03$ \\
Crude Lipid \% & 5.18 & $6.21 \pm 0.15^{\mathrm{b}}$ & $8.76 \pm 1.14^{\mathrm{a}}$ & $6.49 \pm 0.16^{\mathrm{ab}}$ & $5.07 \pm 0.05^{\mathrm{b}}$ \\
Ash \% & 5.72 & $3.99 \pm 0.01^{\mathrm{a}}$ & $4.14 \pm 0.14^{\mathrm{a}}$ & $2.80 \pm 0.04^{\mathrm{b}}$ & $4.17 \pm 0.18^{\mathrm{a}}$ \\
Gross energy (KJ/g) & 6.38 & $6.27 \pm 0.16^{\mathrm{b}}$ & $7.67 \pm 0.55^{\mathrm{a}}$ & $6.42 \pm 0.09^{\mathrm{b}}$ & $6.02 \pm 0.01^{\mathrm{a}}$ \\
Muscle crude protein $\% \%)$ & - & $19.29 \pm 0.22$ & $19.24 \pm 0.26$ & $19.86 \pm 0.10$ & $19.38 \pm 0.98$ \\
Muscle crude lipid (\%) & - & $2.51 \pm 0.76^{\mathrm{ab}}$ & $3.42 \pm 0.22^{\mathrm{a}}$ & $2.46 \pm 0.40^{\mathrm{ab}}$ & $1.50 \pm 0.23^{\mathrm{b}}$ \\
\hline
\end{tabular}

Data are mean values \pm Standard error; means in the same row with the same letter are not significantly different $(\mathrm{P}>0.05)$.

Table 6: Muscle Fatty Acid (\% of Total Fatty Acids) of Til-aqua Red Natural Male Tilapia Fed the Experimental Diets

\begin{tabular}{lllll}
\hline Fatty Acid & FO & AO & RO & FEO \\
\hline $12: 0$ & $2.01 \pm 1.17^{\mathrm{a}}$ & $5.95 \pm 2.14^{\mathrm{a}}$ & $2.58 \pm 0.34^{\mathrm{a}}$ & $5.27 \pm 0.81^{\mathrm{a}}$ \\
$13: 0$ & nd & nd & nd & $0.18 \pm 0.18$ \\
$14: 0$ & $1.93 \pm 0.89^{\mathrm{ab}}$ & $3.29 \pm 0.38^{\mathrm{a}}$ & $2.01 \pm 0.42^{\mathrm{a}}$ & $1.11 \pm 0.13^{\mathrm{b}}$ \\
$16: 0$ & $7.30 \pm 0.06^{\mathrm{c}}$ & $26.60 \pm 2.34^{\mathrm{a}}$ & $18.74 \pm 1.96^{\mathrm{b}}$ & $11.43 \pm 0.22^{\mathrm{c}}$ \\
$16: 1$ & $1.03 \pm 0.11^{\mathrm{a}}$ & $1.64 \pm 0.25^{\mathrm{a}}$ & $1.08 \pm 1.08^{\mathrm{a}}$ & $1.78 \pm 0.29^{\mathrm{a}}$ \\
$18: 0$ & $8.35 \pm 1.74^{\mathrm{b}}$ & $16.49 \pm 0.05^{\mathrm{a}}$ & $14.57 \pm 1.69^{\mathrm{a}}$ & $7.23 \pm 1.35^{\mathrm{b}}$ \\
$18: 1(\mathrm{n}-9)$ & $10.61 \pm 3.06^{\mathrm{c}}$ & $23.72 \pm 0.12^{\mathrm{a}}$ & $20.76 \pm 1.49^{\mathrm{ab}}$ & $14.35 \pm 0.64^{\mathrm{bc}}$ \\
$18: 2(\mathrm{n}-6)$ & $4.30 \pm 1.08^{\mathrm{b}}$ & $13.76 \pm 1.06^{\mathrm{a}}$ & $12.76 \pm 0.09^{\mathrm{a}}$ & $7.45 \pm 1.37 \mathrm{~b}$ \\
$18: 3(\mathrm{n}-6)$ & $1.11 \pm 0.07^{\mathrm{a}}$ & nd & nd & $0.63 \pm 0.07^{\mathrm{b}}$ \\
$20: 2$ & $0.20 \pm 0.20$ & $0.46 \pm 0.46$ & $0.32 \pm 0.32$ & $0.22 \pm 0.22$ \\
$20: 0$ & $0.08 \pm 0.08^{\mathrm{b}}$ & nd & nd & $0.83 \pm 0.07^{\mathrm{a}}$ \\
$18: 3(\mathrm{n}-3)$ & $0.59 \pm 0.17$ & $0.39 \pm 0.39$ & $0.60 \pm 0.60$ & $1.33 \pm 0.04$ \\
$20: 3(\mathrm{n}-6)$ & $58.11 \pm 5.86^{\mathrm{a}}$ & $2.42 \pm 0.25^{\mathrm{d}}$ & $23.30 \pm 2.89 \mathrm{c}$ & $44.75 \pm 1.42^{\mathrm{b}}$ \\
$22: 1(\mathrm{n}-9)$ & $0.29 \pm 0.29$ & $2.52 \pm 2.03$ & nd & nd \\
$20: 3(\mathrm{n}-3)$ & $0.14 \pm 0.14$ & nd & nd & nd \\
$20: 4(\mathrm{n}-6)$ & $0.29 \pm 0.29$ & nd & nd & nd \\
$23: 0$ & $0.88 \pm 0.62$ & $0.27 \pm 0.27$ & $0.46 \pm 0.46$ & $0.29 \pm 0.29$ \\
$24: 1$ & $0.87 \pm 0.16$ & nd & nd & nd \\
$22: 6(\mathrm{n}-3)$ & $1.93 \pm 0.32$ & $2.51 \pm 0.21$ & $2.83 \pm 0.79$ & $3.20 \pm 0.59$ \\
Total saturates & 20.55 & 52.60 & 38.35 & 26.32 \\
Total monoenes & 12.78 & 27.88 & 21.85 & 16.12 \\
Total n-6 & 64.01 & 16.64 & 36.37 & 53.03 \\
Total n-3 & 2.66 & 2.89 & 3.43 & 4.52 \\
Total PUFA & 66.67 & 19.52 & 39.81 & 57.56 \\
n-3/n-6 & 0.04 & 0.17 & 0.10 & 0.09 \\
\hline
\end{tabular}

Data are mean values \pm Standard error; means in the same row with the same letter are not significantly different $(\mathrm{P}>0.05)$. nd, not detected; PUFA, polyunsaturated fatty acid 
Total saturated $(52.60 \%)$ and monounsaturated $(27.88 \%)$ fatty acids were highest in the group fed AO diet while highest total polyunsaturated $(66.67 \%)$ fatty acid was observed in the group that received FO diet.

The condition factor and somatic parameters of Til-aqua red NMT (Table 4) showed no significant variations $(\mathrm{P}>0.05)$ among the experimental treatments. Condition factor in all the groups were higher than 1, indicative of good condition of experimental fish.

\section{DISCUSSION}

The diets were actively fed on by the fish throughout the experimental period. This is indicative of the palatability and acceptability of the diets by the fish. Til-aqua red NMT fed AO, $\mathrm{RO}$ and FEO diets performed as much as or better than those reared on FO diet in terms of growth performance and nutrient utilization. Previous works incorporating vegetable oil sources in tilapia practical diets have also showed better or similar growth and nutrient utilization performances to fish oil based diets.

For instance, $\mathrm{Ng}$ et al. (2001) reported that hybrid tilapia fed semi-purified diets supplemented with sunflower oil and crude palm oil, crude palm kernel oil or palm fatty acid distillates, showed comparable or slightly higher growth compared with fish fed a fish oil-based diet. Red hybrid tilapia fed fishmeal-based diets with various palm oil products as the only added oil from stocking to marketable size grew equally well compared with fish fed a fish oil added diet (Bahurmiz and $\mathrm{Ng}$, 2007). The reason advanced for these positive observations was that tilapias require greater amounts of n-6 fatty acids associated with vegetable oil sources than their n-3 counterparts which are more in fish oil; also vegetable oil sources are known to constitute a more available energy source, thus sparing protein $(\mathrm{Ng}$ et al., 2003). Huang et al. (1998) observed that high levels of $n-3$ polyunsaturated fatty acids (PUFA) depressed growth of tilapia.

Although contrary to this assertion, Santiago and Reyes (1993) reported an improvement in growth of tilapia fed high n-3 PUFA fish oil supplemented diet while Chou and Shiau (1999) concluded that both n-3 and n-6 fatty acids are essential for maximal growth of hybrid tilapia and that these fatty acids must be present in a particular ratio necessary for optimum growth and feed utilization. The results observed in the present study may be due to favourable n-3/n-6 ratio obtained with substitution of fish oil with oils extracted from the differently-processed sesame seed meal in a fishmeal-based diet as earlier advanced by $\mathrm{Ng}$ et al. (2001, 2004 and 2006). The results of the present study were similar to other investigations utilizing vegetable oil sources in tilapia diets (Ng et al., 2006; Bahurmiz and Ng, 2007), and showed that there were no significant differences $(\mathrm{P}>0.05)$ in the somatic indices of fish reared exclusively on oils extracted from differently-processed sesame seed meal when compared with fish oil control.

Expectedly, muscle fatty acid deposition in the present study is consistent with their dietary compositions as previously observed by many authors (Mourente and Bell, 2006; Ng et al. 2006; Bahurmiz and Ng, 2007); except for some observed important variations. For instance, 23:0 (0.27-0.88\% of total fatty acid, TFA) was low in the fillet of Til-aqua red NMT used in the present study when there was a large proportion in the feed (3.76-6.85\% of TFA) compared to the higher concentration of 18:0 (7.23-16.49\% of total fatty acid) whose dietary level was lower (4.93-5.42\% of TFA). This phenomenon has been previously reported by Bransden et al. (2003) and $\mathrm{Ng}$ et al. (2006) for Salmo salar and Oreochromis niloticus, respectively. There was no significant difference $(\mathrm{P}>0.05)$ in 22:6(n-3) (docosahexaenoic acid, DHA) concentrations of Til-aqua red NMT muscle fed oils extracted from differently-processed sesame seed and their concentrations were either slightly lower (control and autoclaved treatments) or higher (roasted and fermented treatments) than their dietary contents.

$\mathrm{Ng}$ et al. (2006) made similar observations and reported that the concentration of $22: 6(n-3)$ in muscle lipid of Nile tilapia decreased only slightly when dietary fish oil was replaced with palm oilladen spent bleaching clay; while Mourente and Bell (2006) observed that muscle DHA was higher than their dietary contents in a study incorporating 
blends of vegetable oils (rapeseed, linseed and palm oils) as replacement for fish oil in European sea bass diet. They suggested selective retention of docosahexaenoic acid (DHA) as a reason for this observation in their studies which may also have been responsible for the result recorded in the present study. Another factor that could be responsible for measurable increase in muscle DHA of the group fed FEO and RO diets could be as a result of modification from sesamin, a sesame lignan known to be abundant in sesame oil (Rangkadilok etal.2010).

In a study assessing the effects of sesamin in fish, Trattner et al. (2008a) found that sesamin/episesamin supplementation increases the level of DHA up to $37 \%$ in white muscle of rainbow trout (Oncorbynchus mykiss) fed with high- $\alpha$-linolenic acid vegetable oil. An in vitro study with Atlantic salmon (Salmo salar) hepatocytes (Trattner et al., 2008b) showed that sesamin/episesamin exposure led to increased elongation and desaturation of ${ }^{14} \mathrm{C} \alpha$-linolenic acid to DHA, confirming that sesamin has modulatory effects on lipid metabolism, leading to increased levels of DHA and higher $\beta$-oxidation activity.

Dietary linoleic acid is known to be responsible for the most detrimental modifications to the fatty acid composition of farmed fish fillets $(\mathrm{Ng}$ et al., 2006; Turchini et al., 2009). In spite of the high content of dietary linoleic acid in the present study, its proportion in muscle was generally low and comparable to those reported in previous investigations evaluating unconventional oil sources as replacement for fish oil in Nile tilapia (Ng et al., 2006) and hybrid tilapia (Bahurmiz and $\mathrm{Ng}, 2007)$. Studies with Atlantic salmon have shown that excessive accumulation of $20: 4(n-6)$ can occur when dietary 18:2(n-6) is high (Dosanjh etal., 1998).

Under these circumstances, 18:2(n-6) is elongated to $20: 2(n-6)$, which is subsequently desaturated to $20: 3 n-6$ and finally to $20: 4 n-6$ using $\Delta 6$ and $\Delta 5$ desaturases respectively. In contrast to this observation, very low level $(0.29 \%$ of TFA) of 20:4n-6 was noticed in the control while this fatty acid was not detected in muscle of fish fed diets $\mathrm{AO}, \mathrm{RO}$ and FEO. However, accumulation of 20:3(n-6) (dihomo- $\gamma$-linolenic acid) fatty acid was noticed in muscle of the group fed FO (58.11\% of total fatty acid, TFA), FEO (44.75\% of TFA) and $\mathrm{RO}(23.30 \%$ of TFA) at a rate inversely proportional to the fillet contents of $18: 2(n-6)$ (linoleic acid); while very small quantity $(2.42 \%$ of TFA) was noticed in the AO diet.

Sesamin has been shown to have several effects on lipid metabolism in mammalian systems. Chavali et al. (1998) reported that sesamin inhibited $\Delta-5$ desaturase activity in rat resulting in accumulation of dihomo- $\gamma$-linolenic acid which could displace 20:4n-6 fatty acid. Gu et al. (1997) noticed a significant reduction in 18:2(n-6) and 20:4(n-6) levels of liver of Brown-Norway rats as a result of combined effects of sesamin with $\alpha$-tocopherol thereby modifying the eicosanoid production and immune function. Shimizu et al. (1989) also reported that incubation with sesame oil increased the mycelial dihomo- $\gamma$-linolenic acid content of an arachidonic acid-producing fungus, Mortierella alpina, but decreased its arachidonic acid, 20:4(n6), content. The factor causing these effects was later isolated and identified to be sesamin (Shimizu et al., 1991). Though dietary sesamin contents of the various treatments in the present study were not quantified, the different processing methods could have affected them which could partly explain the disparity in the extent of accumulated 20:3(n-6). The accumulated 20:3(n6) was highest $(58.11 \%$ TFA) in the control diet (which contained 30\% fermented sesame seed meal and 3\% fish oil) and interestingly followed by diet in which fermented oil replaced fish oil suggesting that fermentation processing and interaction of fish oil with fermented oil may have a role in the accumulated 20:3(n-6) observed under the present investigation.

Sesamin has been reported to have many beneficial pharmacological properties such as antioxidant and antiproliferative activity (Visavadiya and Narasimhacharya, 2008) and lowering cholesterol levels (Visavadiya and Narasimhacharya, 2008). It would therefore be interesting as a matter of future research to study the effects of different processing methods on lignan contents of sesame oil, their accumulation in fish tissues, associated health benefits and their 
specific influences on fish fatty acid profile viz-aviz fillet organoleptic quality. Apart from sesame lignans, sesame seed and oil also contain other important biologically active compounds, such as tocopherols and tocotrienols (Rangkadilok et al., 2010). The deposition of these compounds in fish fillets could also arise from long-term feeding of sesame seed and oil with potential health benefits to consumers. Future research in this area will also be necessary.

\section{ACKNOWLEDGEMENTS}

The authors acknowledge Mrs Korede of Central Research Laboratory, University of Ibadan for technical assistance during fatty acid analysis.

\section{REFERENCES}

AOAC, 1990. Official Method of Analysis (K Helrich, editor) of Association of Official Analytical Chemists, Washington D.C. $15^{\text {th }}$ Edition, Volume.1, 1094pp.

Bahurmiz, O.M. and Ng, W.K., 2007. Effects of dietary palm oil source on growth, tissue fatty acid composition and nutrient digestibility of red hybrid tilapia, Oreochromis sp., raised from stocking to marketable size. Aquaculture, 262: 382-392.

Bendiksen, E.A., Johnsen, C.A., Olsen, H.J. and Jobling, M., 2011. Sustainable aquafeeds: Progress towards reduced reliance upon marine ingredients in diets for farmed Atlantic salmon (Salmo salar L.). Aquaculture, 314: 132-139

Bligh, E.G. and Dyer, W.J., 1959. A rapid method for total lipid extraction and purification. Canadian Journal of Biochemistry and Physiology, 37, 911-917.

Bransden, M.P., Carter, C.G. and Nichols, P.D., 2003. Replacement of fish oil with sunflower oil in feeds for Atlantic salmon (Salmo salar L.): effect on growth performance, tissue fatty acid composition and disease resistance. Comparative Biochemistry and Physiology B, 135: 611-625

Castell, J.D. and Tiews, K. (Editors), 1980. Report of the EIFAC, IUNS and ICES Working Group on Standardization of Methodology in Fish Nutrition Research.
EIFAC/T36, EIFAC/FAO, Rome, 24 pp.

Chavali, S.R., Zhong, W.W. and Forse, R.A., 1998.

Dietary $\alpha$-linolenic acid increases TNF- $\alpha$, and decreases IL-6, IL-10 in response to LPS: effects of sesamin on the $\Delta-5$ desaturation of $\omega 6$ and $\omega 3$ fatty acids in mice. Prostaglandins, Leukotnenes and Essential Fatty Acids, 58(3): 185-191.

Chou, B.S. and Shiau, S.Y., 1999. Both n-6 and n-3 fatty acids are required for maximal growth of juvenile hybrid tilapia. North American Journal of Aquaculture, 61, 13-20.

Dosanjh, B.S., Higgs, D.A., McKenzie, D.J., Randall, D.J., Eales, J.G., Rowshandeli, N., Rowshandeli, M. and Deacon, G., 1998. Influence of dietary blends of menhaden oil and canola oil on growth, muscle lipid composition and thyroidal status of Atlantic salmon (Salmo salar) in sea water. Fish Physiology and Biochemistry, 19: 123-134.

Duncan, D.B., 1955. Multiple range and multiple F tests. Biometrics 11:1-42.

El Khier, M.K.S., Ishag, K.E.A. and Yagoub, A.E.A., 2008. Chemical composition and oil characteristics of sesame seed cultivars grown in Sudan. Research Journal of Agriculture and Biological Sciences, 4(6): 761-766.

FAO, 2014. The state of world fisheries and aquaculture. Food and Agriculture Organization, Rome. 243 pp.

FAO, 2012. The State of World Fisheries and Aquaculture 2012. Rome. 209 pp.

Figueiredo-Silva, A., Rocha, E., Dias, J., Silva, P., Rema, P., Gomes, E. and Valente, L.M.P., 2005. Partial replacement of fish oil by soybean oil on lipid distribution and liver histology in European sea bass (Dicentrarchus labrax) and rainbow trout (Oncorbynchus mykiss) juveniles. Aquaculture Nutrition, 11:147-155.

Furukawa, A. and Tsukahara, H., 1966. On the acid digestion method for the determination of chromic oxide as the index substance in the study of fish feed. Bulletin of the Japanese Society of Science and Fisheries, 32: 502-504.

Gomez, K.A. and Gomez, A.A., 1984. Statistical 
procedures for Agricultural Research, John Wiley and Sons, New York. Pp. 357424.

Gu, J-Y., Tsujita, A., Wakizono, Y., Yamada, K. and Sugano, M., 1997. Combined effects of sesamin with alpha-tocopherol or tocotrienols on lipid and immune indices in Brown-Norway rats. Nutrition Research, 17(2):339-350.

Gupta, M. V. and Acosta, B. O., 2004. A Review of global tilapia farming practices. http://www.enaca.org/modules/news/a rticle accessed 20th March, 2017.

Harris, J. and Bird, D.J., 2000. Modulation of the fish immune system by hormones, Veterinary Immunology and Immunopathology 77: 163-176

Henken, A.M., Lucas, H., Tijseen, P. A. T. and Machiels, M.A.M., 1986. A comparison between methods used to determine the energy content of feed, fish and faeces samples. Aquaculture, 58: 195-201.

Huang, C.H., Huang, M.C. and Hou, P.C., 1998. Effect of dietary lipids on fatty acid composition and lipid peroxidation in sarcoplasmic reticulum of hybrid tilapia, Oreochromis niloticus $x O$. aureus. Comparative Biochemistry and Physiology, 120 (2):331-336

Islam, M.Z., Sardar, R.I. and Akhand, M.R.I., 2015. Growth performance of genetically male tilapia derived from YY male, sex reversed male tilapia and mixed sex tilapia of Oreochromis niloticus in earthen pond aquaculture system in Bangladesh. International Journal of Fisheries and Aquatic Studies, 2(3): 186-191

Kumar, V., Akinleye, A. O., Makkar, H. P. S., Angulo-Escalante, M. A and Becker, K., 2012. Growth performance and metabolic efficiency in Nile tilapia (Oreochromis niloticus L.) fed on a diet containing Jatropha platyphylla kernel meal as a protein source. J. Ani. Phy. Ani. Nutr. 96(1):37-46

Mourente, G. and Bell, J.G., 2006. Partial replacement of dietary fish oil with blends of vegetable oils (rapeseed, linseed and palm oils) in diets for European sea bass (Dicentrarchus labrax L.) over a long term growth study: effects on muscle and liver fatty acid composition and effectiveness of a fish oil finishing diet. Comparative Biochemistry and Physiology B, 145: 389-399.

Mukhopadhyay, N. and Ray, A. K., 1999. Improvement of quality of sesame, Sesamum indicum seed meal protein with supplemental amino acids in feeds for rohu, Labeo rohita (Hamilton) fingerlings. Aquaculture Research 30(8): 549-557.

Nash, R.D.M., Valencia, A.H. and Geffen, A.J., 2006. The origin of Fulton's condition factor - setting the record straight. Fisheries, 31: 236-238

Ng, W.K., Lim, P.K. and Sidek, H., 2001. The influence of a dietary lipid source on growth, muscle fatty acid composition and erythrocyte osmotic fragility of hybrid tilapia. Fish Physiology and Biochemistry, 25:301-310.

Ng, W.-K., Lim, P.-K., and Boey, P.-L., 2003. Dietary lipid and palm oil source affects growth, fatty acid composition and muscle $\alpha$-tocopherol concentration of African catfish, Clarias gariepinus. Aquaculture, 215:229-243.

$\mathrm{Ng}$ W.-K., Wang, Y., Ketchimenin, P. and Yuen, K.H., 2004. Replacement of dietary fish oil with palm fatty acid distillate elevates tocopherol and tocotrienol concentrations and increases oxidative stability in the muscle of African catfish, Clarias gariepinus. Aquaculture, 233: 423-437.

Ng, W.-K, Koh, C.B. and Zubir, B.D., 2006. Palm oil-laden spent bleaching clay as a substitute for marine fish oil in the diets of Nile tilapia, Oreochromis niloticus. Aquaculture Nutrition, 12: 459-468.

Olude O, George, F. and Alegbeleye, W., 2016. Utilization of autoclaved and fermented sesame (Sesamum indicum L.) seed meal in diets for Til-aqua natural male tilapia, Animal Nutrition, 2: 339-344

Rangkadilok, N., Pholphana, N., Mahidol, C., Wongyai, W., Saengsooksree, K., Nookabkaew, S. and Satayavivad, J., 2010. Variation of sesamin, sesamolin and tocopherols in sesame (Sesamum 
indicum L.) seeds and oil products in Thailand. Food Chemistry, 122: 724-730.

Santiago, C.B. and Reyes, O.S., 1993. Effects of dietary lipid source on reproductive performance and tissue lipid levels of Nile tilapia Oreochromis niloticus (Linnaues) broodstock. Journal of Applied Ichthyology, 9:33-40.

Shimizu, S., K. Akimoto, H. Kawashima, Y. Shinmen and Yamada, H., 1989. Production of dihomo- $\gamma$-linolenic acid by Mortierella alpina 1S-4. Journal of the American Oil Chemists' Society, 66: 237241.

Shimizu, S., Akimoto, K., Shinmen, Y., Kawashima, K., Sugano, M., and Yamada, H., 1991. Sesamin is a potent and specific inhibitor of $\Delta 5$ desaturase. Lipids, 26:512-516.

Subasinghe, R. P., D. Curry, S. E. McGladdery and Bartley, D., 2003. Recent Technological Innovations in Aquaculture. Pages 59-74 in Review of the State of World Aquaculture, FAO Fisheries Circular No. 886 (Revision 2). Inland Water Resources and Aquaculture Service, Fishery Resources Division, FAO Fisheries Department. Food and Agriculture Organization of the United Nations. Rome, 2003.

Trattner, S., Kamal-Eldin, A., Brannas E., Moazzami, A., Zlabek V., Larsson P., Ruyter B., Gjoen, T. and Pickova, J., 2008a.
Sesamin supplementation increases white muscle docosahexaenoic acid (DHA) levels in rainbow trout (Oncorbynchus mykiss) fed high alpha-linolenic acid (ALA) containing vegetable oil: metabolic actions. Lipids, 43: 989-997.

Trattner, S., Ruyter B., Ostbye, T.K., Gjoen, T., Zlabek, V., Kamal-Eldin, A. and Pickova, J., 2008b. Sesamin increases alphalinolenic acid conversion to docosahexaenoic acid in Atlantic salmon (Salmo salar L.) hepatocytes: role of altered gene expression. Lipids, 43: 9991008.

Turchini, G.M., Torstensen, B.E. and Ng, W.-K., 2009. Fish oil replacement in finfish nutrition. Reviews in Aquaculture, 1: 1057.

Visavadiya, N. P., and Narasimhacharya, A. V. R. L., 2008. Sesame as a hypocholesteraemic and antioxidant dietary component. Food and Chemical Toxicology, 46(6): 1889-1895.

Wang, M. and Lu, M. 2016. Tilapia aquaculture: a global review. Aquaculture Research 47: 2363-2374

Yoshida, H., and Takagi, S., 1997. Effects of seed roasting temperature and time on the quality characteristics of sesame (Sesamum indicum) oil. Journal of the Science of Food and Agriculture, 75: 19-26. 